\title{
Changing Play - writing, researching and learning in an early years arts project
}

\author{
Anton Franks and Pat Thomson \\ University of Nottingham, School of Education, Nottingham, UK \\ Published online in Ethnography and Education, 15 February 2019 \\ https://www.tandfonline.com/doi/full/10.1080/17457823.2019.1579659
}

\begin{abstract}
'Changing Play' is an ongoing project initiated by education curators from the Serpentine, a prestigious London art gallery, working with the Portman children's centre nursery. Viewed by curators as a collaboration between artist, children's centre staff and parents, and the gallery, Changing Play combines art and action research, and expands the boundaries of the gallery. In the words of one of the education curators, 'the project is about social change'. It is not for the gallery curators to develop proposals but to 'co- develop work'. Ethnographic evidence employing narrative, visual arts informed analysis is being used by the gallery to report to funders, inform iterative planning and inform future directions. The paper focuses on methodological questions on ways in which ethnographers might meet artistic projects both during and after being in the 'field'. It takes the form of a 'loose parts' montage which reflects the ways in which the art project was conducted.
\end{abstract}

\section{Keywords}

Modes of ethnographic research; ethnographic writing; community-based arts and play; gallery sponsored community-based arts and play; community- based arts and play curation; communitybased arts and social change 
In early childhood, there is no important difference between play and work, art and science, recreation and education - the classifications normally applied by adults to a child's environment: education is recreation, and vice versa ... (Nicholson 1972, 5)

Nicholson's theory of 'loose parts' - interchangeable materials that can be used in multiple designs developed through play - was the main inspiration for the early childhood programme we have been researching. It was also a guide to the way in which we have thought about the practice of ethnographic research and our writing. Here, we invite readers to reassemble our loose textual parts to re-make 'arts' play and arts research. This invitation might seem, at first sight, to delegate the responsibility for interpretation to the reader. But this is not the case. The fragments that appear in this text, as is the case with other ethno- graphic writing and with art works and art events, have been selected and worked on - curated - in order to steer the reader in particular directions. But we have knowingly abandoned the genre of social science argument in favour of what anthropologist Michael Taussig describes as 'a mode of writing that links the writing with what the writing is about' (Taussig $2018,192)$. We discuss this, and other methodological questions, later.

The paper concerns an arts initiative called Changing Play, conducted by the Serpentine Gallery with/in the Portman Early Childhood Centre. Readers will immediately notice that we have named the gallery and the centre. This is with explicit permission, but also in recognition that (1) it is impossible to disguise the identity of a distinctive project with an easily found web presence, and (2) as Nespor (2000) points out, there is a fine irony in anonymising place when it is crucial to the people and project being researched. Changing Play does not take part in a vacuum but is the current manifestation of a seventy-year engagement between the Serpentine and its local communities and locale. We explain this history after setting the scene for the research.

\section{Part One: Researching - a snapshot}

Sitting against a wall of an outdoor play area attached to a nursery on a warm afternoon in central London, is a researcher, Anton Franks, pen poised, notebook in hand. The nursery is situated in a densely populated, linguistically and culturally diverse area, surrounded by apartment blocks of social housing. This is where most of the nursery's children live with their families, many of whom are on low incomes. Part of an early childhood centre, the nursery has for some time participated in a communitybased arts programme run by education curators working out of the Serpentine, a well-known London gallery. As Anton settles, the children are still at lunch inside the nursery, so the yard is fairly quiet, with just the hum of the city in the background.

Laid out in the play area is a range of materials - transparent sheets, reflective insulation sheeting, foam tubes and sheets, circles and triangles, sourced from DIY shops and scrap stores. The materials are part of a kit assembled by an artist, Albert Potrony, who has been commissioned by the gallery after discussion with staff at the early childhood centre to work on the project known as "Changing Play'. Together with Albert, education curators, Alex Thorp and Ben Messih, have arranged this collection of 'loose parts' (Nicholson 1972), materials that are made available for the children to play with in any way that they choose. Artist, curators and nursery staff will participate in the children's play, but the curators are clear that they want the children to take the lead. The adults should follow, helping the children to develop their play with this 'stuff'. Initially, the researcher thinks that he will try to sit apart in his role as ethnographic researcher, observing and taking notes describing the children's activity. When the children's lunchtime is over, they spill out of the nursery into the yard with some excitement and expectation - Albert has been working with them for a few weeks now and they have a sense of what awaits them.

It takes just a few minutes for one child to notice the researcher sitting against the wall. He is at their level, in their eye-line. An exuberant and smiley boy, approaches and asks what the researcher is doing. Anton replies that he's interested in watching them play with the stuff that Albert has provided. The boy licks Anton's cheek and, soon, two other children cluster around. One has hold of a plastic clip that Albert which she clips to Anton's shirt, pinching his skin, making him give out a yelp and a giggle. The pen and notebook have to be stuffed into his pocket. From now on, the note-taking on the play of the children as it happens has to lurch forward in fits and starts. Complete physical immersion in the 
play, and its 'artfulness', takes priority. Observation becomes fused with participation. Henceforward, 'sense-memory' (Stanislavsky 1967) held in the researcher's body as a participant has inescapably become woven into the research process.

Over time it became clear that active involvement in the process of art-making play was par for the course. Research on the project could not happen, it had to happen inside the art world (Becker 1984) or rather, the play-art-world of the Changing Play project. The ethnographer was not a detached observer but was rather another 'loose part' in the assemblage of children, artists, learning curators, early childhood staff, materials, events and space/place. Even when the pieces fell apart at the end of field work, embodied memories of taking/being part were/are re-animated through field notes and photographs.

We wondered how we might continue to participate in art-play while writing about it for those who were not there.

\section{Part Two: Serpentine local, the context for the research}

The Serpentine Galleries are set in forty acres of parkland around the Serpentine lake in central London. They are bounded on one side by up-market Hyde Park and Kensington Gardens. The lake is home to an elite swimming club and the park hosts a marathon and running club. The gallery is physically separated from surrounding neighbourhoods. The boundaries around and relative isolation of the two gallery buildings are perhaps a neat metaphor for the elite cultural experiences on offer inside. However, the gallery has a commitment to equity and access, epitomised through the practices of its learning team.

For the last 10 years Serpentine have run a community arts project centred on the Edgware Road. The project is not an 'extension' project run in community buildings simply because the galleries are too small, or that some of the immigrant and low- income residents nearby would not see the gallery as 'their place', although both of these are likely to be true. The Edgware Road project emanates from the socially engaged commitments and practices of contemporary artists and curators. An important element of the institutional critique of the elite nature of art and the commercialism of the art market has been the development of a wide range of programmes and projects which seek to work 'locally' bringing artists and residents together to hold conversations, make work and address local issues.

Serpentine's Edgware Road project has historical antecedents in the collaborative and experimental arts projects run by artist Marie Paneth with local children (Paneth 1944), and subsequently George Goetschius and Joan Tash who worked with local 'unattached' young people researching lives and livelihoods, often through film-making (Goetschius and Tash 1967). The Edgware Road Project continues this work through focusing on the council housing estates and towers that sit alongside much wealthier, privately owned housing. The project operates through The Centre for Possible Studies, a 'pedagogical project' which offers 'a convergence point in which artists, neighbourhood residents and workers and scholars might collaborate on studies born of a kind of thinking in and with the complex conditions and transactions of the road (https://centreforpossiblestudies. wordpress.com/about/)'.

At any one time the Edgware Road programme has several funded projects operating. Changing Play is one strand of a wider initiative called World Without Walls. Changing Play was designed to provide a resource to early childhood, understanding that the sector was experiencing both ongoing funding pressures and a strong push to become more school-like and focused on preparation for school (Lewis 2018). Gallery support for play through artists commissions, was designed to support early childhood staff to resist the push for quantification (Elwick et al. 2018), as well as to maintain pedagogies which promoted exploration and risk-taking which required curiosity, imagination and agency.

But rather than offer a series of projects to a number of early childhood centres, Serpentine gallery learning curators initially formed a strong relationship with the Portman Early Childhood Centre in Westminster. The Portman serves the Church Street area, recently designated a priority for 
regeneration. Church Street is currently ethnically diverse, with a large Arabic heritage population, the vast majority of whom survive on modest incomes and live in social housing. The Portman caters for these families. It offers a crèche, nursery school, family support, parenting workshops, adult education, an employment drop-in, a toy library, a child-minders' group, a multi-sensory room, advice sessions and family support panel. Open 50 weeks of the year and from 8 am to 6 pm, it is rated 'outstanding' by Ofsted (England's education inspection body) and praised for its attention to children's learning. The Serpentine is now working with the Portman to offer resources and approaches developed in Changing Play to other early childhood providers around Edgware Road.

Changing Play is not 'outreach' work - Alex and Ben are clear about this - it is firmly communitybased, arts projects that extend the boundaries of the gallery. This fulfils the gallery's obligation to civic responsibility. More importantly, 'art' is understood as an agent of change. As Nicholson puts it

... if we are to build a society in which individuals and communities have greater control over the loose parts with which their environment may be constructed - loose parts that are at present controlled and fixed by an inflexible education system and cultural elite ... (Nicholson 1972, 12)

The commitment to art as emancipation is not unique to the Serpentine but is a widely- held view in the contemporary arts community. There is however considerable debate about what would count as transformation and how it might be achieved (Kester 2011 ; Bishop 2012). There is no space here to detail the various debates about socially committed art practices but is worth noting that in London in particular there is a great deal of activity and critique of programmes in areas such as Church Street. Artists are often accused on being the front-runners of gentrification, 'art-washing' plans to clean up and clear out long-term poor residents (Pritchard 2017). It is thus important to note that the Serpentine collaboration with the Portman aims to strengthen a local institution catering for the most disadvantaged, and not to create stand-alone arts 'resistance' able to be easily appropriated into new middle-class mores.

The Serpentine Edgware Road programme has a strong focus on (1) the recognition of local knowledges, interests and narratives, (2) the development of an arts programme which is reciprocal, of interest to all involved, and (3) the use of participatory and collaborative approaches. Five key themes inform work across the World Without Walls programme: migrations and movements; rights to the city; children's right to play; the politics of care; and rethinking schooling. Children and young people are not thus defined by the Serpentine on the basis of their educational status, but as members of a community. 'Schools don't exist as islands,' Alex tells Anton, they are part of a neighbourhood that reflects local demographics.

The community-based arts programmes initiated by the education curators at the Serpentine require co-development through continued negotiation of role and, activities. Although firmly anchored in arts practices, Alex and Ben saw dialogue and collaboration - involving children, artists, centre staff and members of the wider community - as a guiding principle for the arts projects they curate. In the case of Changing Play, the centre's staff wanted to develop the scope of children's play so that it could be shared with parents. The Serpentine response was to co-develop the project.

The curators' initial task was to commission an artist that might help them develop shared ideas. Alex and Ben selected artists with varying ethnic and racial cultural practices and languages, as well as ensuring gender balance across commissions. Artists chosen all had participatory practices. The curators' task was then to facilitate discussion between the centre's staff and the artist so that the project could be developed. Collaboration was initially between the three parties. During the projects the emphasis was on artists and staff recording, talking with and responding to children and parents in order to negotiate week to week activities. This was akin to the process of pedagogic documentation used by atelierista in Reggio early childhood programmes (Vecchi 2010; Gandini et al. 2005) Reggio writings had been influential for learning curators and Portman centre staff alike. Between individual commissions, the learning curators discussed the projects to date, and developed ideas for the next commission. 
Changing Play used an iterative collaborative planning model in which: projects were initially designed by learning curators and centre staff; the general direction of the project was then collaboratively planned by the learning curators, centre and staff and artist; and learning curators, artist and centre staff 'followed children' - they documented what was happening, paying particular attention to children's interests, activities and conversations eliciting feedback from parents. This gradual giving over of responsibility for ways in which each commission developed, and for the ongoing commissions themselves, was not co-design as it might sometime be understood and realised. Families had not been involved in deciding that a project on play was needed. Nor were they involved in deciding the focus for commissions or for commissioning artists. Centre staff however were.

During the projects, a responsive pedagogy of conversation and careful observation and documentation was used to try to ensure that families and children influenced the direction each commission took. This approach is congruent with Rancièrian principles of spectator emancipation - of democratisation through the creation of 'third things', events and spectacles through which artist and community come together to create some- thing that neither of them had initially envisaged (Rancière 2009).

\section{Part three: Changing Play - positioning the research and researchers}

We understood at the outset that the iterative planning approach adopted by the education curators was directly influenced by participatory philosophies of art and of research. Research was held to be important throughout the process in varying ways. However, our position in this research was far from clear.

Research was important as a way of beginning the project to ensure that everyone was philosophically attuned. Alex and Ben were aware that collaborative work, especially work with young children, does not necessarily come easily to artists. 'Artists often don't have a very developed understanding of the ways that people can be different,' they tell Anton. Neither do they perceive artists as being good at 'letting things evolve' - their experience leads them to understand that 'not many artists fit with interactive approaches.' But the education curators were keen to 'let the children lead' the activity, and 'not get involved in routine stuff.' In support of their approach, and in a bid to feed into Albert's thinking and practice, Alex sent him readings, particularly 'The theory of loose parts' (Nicholson 1971), another piece by artist Palle Nielsen (Gether et al. 2015) and, later, a chapter by Gunilla Dahlberg and Peter Moss - 'Towards a pedagogy of listening' (2004). Architect, planner and academic Nicholson writes about the creative capacities of children and how adult designers often thwart or restrict this potential -

Children greatly enjoy playing a part in the design process: this includes the study of the nature of the problem; thinking about their requirements and needs; considering planning alternatives; measuring, drawing, model-making and mathematics; construction and building; experiment, evaluation, modification and destruction. (Nicholson 1972, 12)

'Listening to what the children are saying is important,' Alex says, 'Listening is a radical act, necessary to understanding what [children] are doing.' The influence of child, art- centred approaches developed in Reggio Emilia (Rinaldi 2005) can be clearly detected in this approach.

Research also informed the ways in which artists, learning curators and centre staff were to become child-led. Listening had an expanded and metaphorical meaning, not simply referring to aural qualities, but attuned to the many ways that the young children communicate through their whole activity - play with objects, how objects are used, gestures, expressions and interactions with peers and adults, and so forth. Such a multimodal approach to making meaning (Kress and van Leeuwen 2001), particularly as it is applied to young children, resonates strongly with a 'mosaic approach' to research with (Clark and Moss 2001) which we adopted as integral to our ethnography, because we too were to be sutured into the iterative planning process. 
Research was also key to project accountability. We were employed on Changing Play as evaluators, as required by the programme's funders. But Alex and Ben also wanted us to work as co-researchers who were in close conversation with them. They wanted their iterative model of planning to be research-informed. They told us that Changing Play was 'about promoting change, hence the research element' of projects. They wanted to 'build networks locally'. Then, from this local base, their aspiration was to develop toolkits from the work to share the work nationally and, perhaps, internationally. Alex also wanted 'to see continuity and development', to 'avoid parachuting in' by 'inviting people to do research' alongside the artist and education curators. We were to help in this process. The education team prepared the ground for us and our research by gathering a sense of 'familiarity with the community and their values.' We were then to engage in ongoing conversation with them, to feed in emerging analysis and insights into their iterative process.

Our research did not stand apart from the whole activity but was intended to feed holistically into the creative potential of the art-making process. Art-making was fore-grounded, seen as integral to an iterative process of reflection-planning-research. But, at the same time as participating in the art-led action research programme, we had to under-stand and document processes and outcomes in order to fulfil evaluative requirements - to identify and understand the benefits and outcomes for all participants, children, artist, gallery and nursery staff. We had to develop an understanding of its systems, relationships, activities, events and conversations. We chose to do this as ethnographers, thus to be both integrated participants and detached observers at the same time.

We decided that we had to join in the project processes of ongoing pedagogic documentation and reflection. We were part of the participatory action research project that was Changing Play. But we were also in a direct commissioned relationship, answerable to the Serpentine learning curators just as commissioned artists were. We had spent time at the beginning of the project talking to the education curators in order to understand the scope of their education programme, its underlying principles, the processes by which they initiated projects with particular groups and institutions and, importantly, their aspirations for the projects and the outcomes that they hoped for and expected. Alongside these wider considerations, we needed to discuss specifics of the project - locations, schedules, participants etc. as well as establishing lines of communication for gathering informed consent from the various participants. As the time allocation for research was inevitably limited, a schedule of research visits was negotiated, initially with the education curators, and later with the involvement of the artist. This made us much more like externalised 'experts', a position we were all keen to undermine (see field note memo 1).

The ongoing commitment to collaboration and conversation leads to some blurring of positions - artist, participant researcher, curator. The artist is researching the project while he is working. He takes photos, keeps a journal. He wants to interact with Anton. He makes his records and images available to us. Alex and Ben, the learning curators are keen to continuously reflect on the project as it progresses. They organise reflection sessions, to which Alex's documentation and Anton's immediate observations contribute. They circulate the occasional text which offers theories of play, early childhood and art. Anton takes photos and, like Alex and Ben, takes part in the activities Albert organises, becoming artist assistants. All are implicated in, and working for, a community arts empowerment project.

We decided that Anton should not observe the project at its very start, but should visit once the project was underway, allowing Albert to establish a relationship with the children. Before the first research visit, Anton arranged to meet Albert in a rooftop cafe' nearby the early childhood centre. They met on the staircase to the cafe' - Anton asked Albert how it was going, to which Albert replied, 'It's a mystery!' Up the stairs, as they settled with their coffees, Albert opened his laptop and narrated his way enthusiastically and rapidly through a set of images he had taken of the children playing with materials, both inside the nursery and in the outdoor play area. The meeting lasted an hour, with Anton interjecting with just a few prompt questions to gather some sense of Albert's participatory practice and, in particular, his experience in working with children.

Afterwards, Anton participated in three Changing Play sessions at Portman. The first two were in the outdoor play area attached to the nursery. He arrived before the session, helped to lay out the materials and then participated for the two hours following, talking and playing with the children when they wanted to involve him, and snatching moments to snap photographs and take notes when the opportunity arose. During the course of the second session, Albert had printed images of the children's play and took individuals inside and asked them about what they were doing, eliciting narratives on their play with the materials from the children. Albert audio-recorded these sessions. Throughout, Anton also had conversations with Albert, education curators Alex and Ben, and nursery staff when he 
felt it appropriate and part of the ongoing flow of activity. At the end of the nursery day, when parents and carers had collected their children, Anton joined in with Albert, Alex, Ben and the nursery staff (including the head of the Portman) sitting in a large circle and engaging in post-session discussion, sharing reflections on the session's activities and gathering advice for how to proceed in the next sessions.

Anton observed Albert's final session working with the children. On this occasion, Albert had mounted a number of images, taken during the previous weeks, with sticky putty on large cardboard sheets featuring particular children. The sheets were displayed in a small room inside the centre. He invited children, accompanied by their teacher, to come into the room, to choose images of themselves that they liked and to talk about them with him. Anton observed silently, not engaging in conversation and taking no photographs. After the project, Anton arranged a telephone conversation with Albert, garnering his reflections on the project, particularly focusing on what he felt were the outcomes for the children and for himself as the artist.

Since then, Albert has produced a toolkit comprising of a booklet and a pack of cards with images and quotes from children, parents and staff on the project, and these too have informed our research.

Field note memo 1

Our positioning as researchers was, and remains, difficult to pin down We shared with the learning curators a desire to do something to support the everyday play-oriented pedagogies of the centre. We also shared their political commitment to interventions that might make a difference to the ways in which Conservative government public policies was making everyday life increasingly difficult for the poorest residents around Edgware Road, while the wealthiest profited. But we were not co-producers of Changing Play. While commissioning and project design were an ongoing process of negotiation and adjustment, this was something we were able to document but not influence. However, we were integrated into conversations about the ongoing participatory iterative planning. Sometimes, we talked with the learning curators about their wider education programme, and they asked us for our views and about research and practice in other national and international contexts. We were a source of new information not only for the ongoing cycles of action research, but also for the direction of the gallery learning programme more generally. We saw this conversation as part of the partnership we had formed. Nevertheless, when it came to writing reports for funders we were once again detached and on our own.

At the time, this kind of ambivalent researcher experience felt as if it were part and parcel of our lives as academics in highly modernist universities - at once having to perform by acquiring research funds and publishing for audit purposes while at the same time producing knowledge that might help to make a small difference in the world (Holmwood 2011; Barnett 2010). Our everyday academic lives were lived in various combinations of resistance and conformity (Tuck and Yang 2014), of pleasure and performative terror (Ball 2003). Juggling multiple demands and subject positions was familiar territory.

But as ethnographers, we were in slippery positions. Pat Thomson has written else- where about the ways in which her identity as a researcher shifted throughout a pupils-as-researchers project (Thomson and Gunter 2011); that paper referred to Bauman (2000) and his exposition of the ways in which the conditions of high modernity, had stripped certainty from all aspects of everyday life. In such conditions, individuals are liquid. Who we are and who we might be are highly fluid, nomadic, contingent on circum- stances, Bauman, argued, and likely to change from moment to moment. The same kind of shifting was also characteristic of our engagement in Changing Play. We were at once variously positioned as participating action researchers, detached evaluators, co-researchers with curators, critical friends to curators, and university experts able to speak with authority about Changing Play in public events. Who we were as 'the ethnographer' was not fixed but multiple and mutable. We were many kinds of partial ethnographers, with diverse purposes, identities and tasks in tension.

Part Four: Writing ethnography - orientations to research and text 
How are we to describe the kind of ethnography this was? We can describe our research in the kind of terms used in research proposals. Our methodology was ethnographic case study. We used four main data generation methods - these can be broadly characterised as narrative interviews, immersive participant observation (supported by broadly drawn observation schedules), ongoing discussion with various participants (children, artist, education curators, nursery staff) in the course of the project, and visual data in the form of still and moving digital images. Some of the visual data were generated by the researchers, but still images taken by the artist and curators served as additional sources of data. Documentary evidence - of project proposals, strategy documents, and readings collated by the education curators and shared with the artist - provided contextual information which helped to form a sense of the ethos and theories that guided the inception and process of the project. This description of method has been critiqued by anthropologists, from Geertz (1973) onwards. The research appears linear, rational and objective - a pseudo- scientised version of a research tradition that relies on researcher subjectivity and interpretation practiced with integrity and high degrees of reflexivity (Thomson 2018).

Our research was a very particular ethnographic 'mess' (Law 2004). The collaborative work we could do was limited by the ways in which Changing Play was designed - the evaluative questions we addressed were determined before we arrived; the ongoing conversations we were asked to participate in were guided by the learning curators and artists, who were themselves in conversation with centre staff and parents. We might have entertained the possibility of enlisting parents as coresearchers or centre staff, but this seemed much too difficult in practice - time being a major factor as well as desire, why would staff or parents want to research the programme when we were already there? There was as well a real consideration of the ways in which a focus on research might interfere with the pro- grammatically oriented conversations that were vital to iterative planning. However, the programmatic conversations were research-like. Learning curators, centre staff and the artist documented what they saw each session and reflected on it, a process typical in participatory action research.

We wanted to present our ethnographic experiences in our text. Anthropologists have been experimenting with questions of text and representation for a long time. More recently however attention has shifted to think about textual forms as being something over and above representation a text does something, it leads to action, it accomplishes particular kinds of work in the world. This 'doing' occurs between the text and the audience, the materials provided by the anthropologist steer the audience in particular directions - they afford some things and not others, but they are also infinitely variable and subject to the ways in which audiences interpret them. In anthropology and other disciplines which use ethnography we now see:

- filmed, performative and sensory ethnographic works which take an audience away from their accustomed meaning-making practices to focus instead on embodied affective responses which are difficult to capture only in words (Pink 2006, 2009; Conquergood 2013; Denzin 2003),

- social fictions which translate patterns of behaviours, interactions, rituals, and beliefs into forms that engage audience imaginations (VanSlyke-Briggs 2009; Pandian and McLean 2017),

- $\quad$ work which builds a new vocabulary to problematise (Rabinow 2007; Rabinow et al. 2008) and reconceptualise and describe the 'devices' (formerly understood as methods) which 'assemble the material and social conditions necessary for the joint construction of knowledge' (Criado and Estalella 2018)

- attempts to harmonise ethnographic texts with their subject matter. It is this latter quest with which we have engaged in this paper.

We have thus been very interested in the work of Michael Taussig - Taussig has long been concerned with bringing what he is researching together with how he thinks and writes. He describes this in The nervous system (1992) as making 'the matter of spirit the spirit of matter'; in that book this correspondence entailed the construction of judder- ing, nervy prose which juxtaposed 'incantatory spells of mimetic realism' achieved through a 'judicious quoting of "the real"' (6) with passages written as reflexive, philosophical stream of consciousness. Taussig often uses literary forms that are also integral to the culture in which he has been immersed. For instance, in The magic of the state, (Taussig 1997) he adopted the genre of magical realism - the form harmonising with the subject matter. The 
authorial sensibility through which the book was written was that of someone who had at least partially inhabited and become part of the world being studied. Similarly, his engagement with the Occupy movement led to l'm so angry, I made a sign (Taussig 2012), a text written in the continuous present, spanning three months, mirroring a walk through the Wall Street encampment. Taussig often refers to Michel de Certeau (de Certeau 1988). De Certeau compared the 'tactics' of day-dreaming and walking flaneur-like through the city to the ways in which everyday writing could challenge the orthodoxies of the 'scriptural economy' of normative knowledge pro- duction - an aim also shared by Taussig. Walter Benjamin's episodic approach to knowl- edge production and writing, epitomised in The Arcade Project (Benjamin 2002) is perhaps a major influence on Taussig. who wrote a similarly flaneur-like structured book about visiting Benjamin's grave (Taussig 2006).

Taussig's work has encouraged us to think about how we might write the mess and epi- sodic nature of our ethnographic work. We were also minded to position our work some- where in the arts-based research field. But we are not arts-based researchers who focus on the use arts as method (Leavy 2009; Jones 2006), although we did make images. Nor were we committed to taking up an arts form as a means of representing our experience more evocatively, in ways that would provoke an emotional and aesthetic as well as a cognitive response (Barone 2000).

We were particularly interested in thinking how we could work with contemporary arts ontoepistemology/ies - an orientation to seeing, understanding and being in the world. These include, inter alia: that not-knowing is more important than knowing (Fisher and Fortnum 2014); that art is made between the object or event and the spectator (Mitchell 2005); that interpretation produces unending 'difference' rather than a unified and universalist truth (Derrida 1978); and that 'practices of knowing' mean developing a line of inquiry which may be episodic and fragmented. To research something in an effort to 'know' can be thought of as becoming entangled in an affective mesh (Ingold 2011), where one pieces together insights, sensations, memories, desires, analysis and theories. Variations of this onto-epistemological stance are already evident in publications which address the intersection of arts and ethnography (Schneider and Wright 2010; Schneider and Wright 2013), and in the published works of collaborating artists and ethnographers.

Our concerns with text as social action, with ethnography that textually becomes what is being researched, and contemporary arts onto-epistemologies have led us to adopt the montage genre in this, and other related writings (Thomson). Montage is a form of narrative achieved through the juxtaposition of 'chunks' of image, objects and/or text, where the meaning is not only in the individual elements, but also in their inbetween and over- laps (Berger 1997). Following one discrete chunk with another asks that a viewer/reader

construct a joining narrative; while the chunks delimit, the viewer/reader is invited to add their own meanings to the resources provided (Elsaesser and Hagener 2016). Montage is commonly used in film and literature as well as music, visual and performing arts. It is also sometimes taken up in educational research - for example, MacLure, Holmes, MacRae and Jones (MacLure et al. 2010) adopted montage in making a film. They juxtaposed footage taken in early childhood classrooms with layered images from a range of contexts overlaid with images of text taken from field notes, transcripts and discussions, as well as policy document, academic and popular texts. The goal was to 'set the images free from the enclosures' (548) of orthodox social science argumentation, cut common ways of seeing and saying classroom behaviours out of their accustomed frames, but nevertheless to reveal patterns of concerns. They were not simply interested in montage as a representation but also in the work that it asked of the viewer to grapple with the 'unsaid'. MacLure (MacLure 2010) talks elsewhere about this assemblage-oriented educational research, including montage, as 'baroque method' which resists a single point of view; a method which eschews the 'strictures' of scientised approaches to text (Riddle, Bright, and Honan 2018).

The notion of montage as a research writing practice resonates with the 'loose parts' espoused by Serpentine as the core of their educational programmes. However, we have been much less experimental with the actual writing of each of our sections than we might perhaps have been, 
suggesting perhaps our reluctance to stray too far away from the comprehensible writing usually favoured by educational ethnographers. Our experimentation is confined at this point in time to resist the call of over-neatly delineated argument.

\section{Part Five: Research writings as loose parts}

Throughout the project we have had to produce different kinds of writing. In addition to field notes and inbetween memos that bring theory together with literatures in order to advance our thinking (Coles and Thomson 2016), we have also worked with images and continued to look for a way to present an almost entirely wordless narrative that would provoke discussion about what can be 'seen' by an observant participant (see Figure 1). We have also produced descriptions such as the one that opened this paper. However, visual texts, and the kind of textual montage we have produced here, sit alongside the 'milestone' reports which were integral to our contracted evaluation obligations.

The evaluation genre is that of a report, with a predictable format - introduction, methods, results and discussion, recommendations (Swales 1990). The writer of a report is that of a detached expert, and this is manifest in the use of the third person - the omnipotent god-like figure who speaks from everywhere and nowhere, as Donna Haraway (1990) famously had it. Report writing also adopts facticity - this is what happened - that brooks no uncertainty. The regular use of bullet point lists is indicative of a style of writing which is focused on unequivocal statements piled up one after another. This is of course the very writing that anthropologists and others who took the 'linguistic turn' rejected (Thomson 2018). Evaluative writers, as the 'value' in evaluation suggests, also make strong judgements about what has been achieved and whether a project has met its stated objectives. An evaluative writer stance sits strongly at odds with an ethnographic which acknowledges specificity and partiality (see example of report writing in Figure 2). 

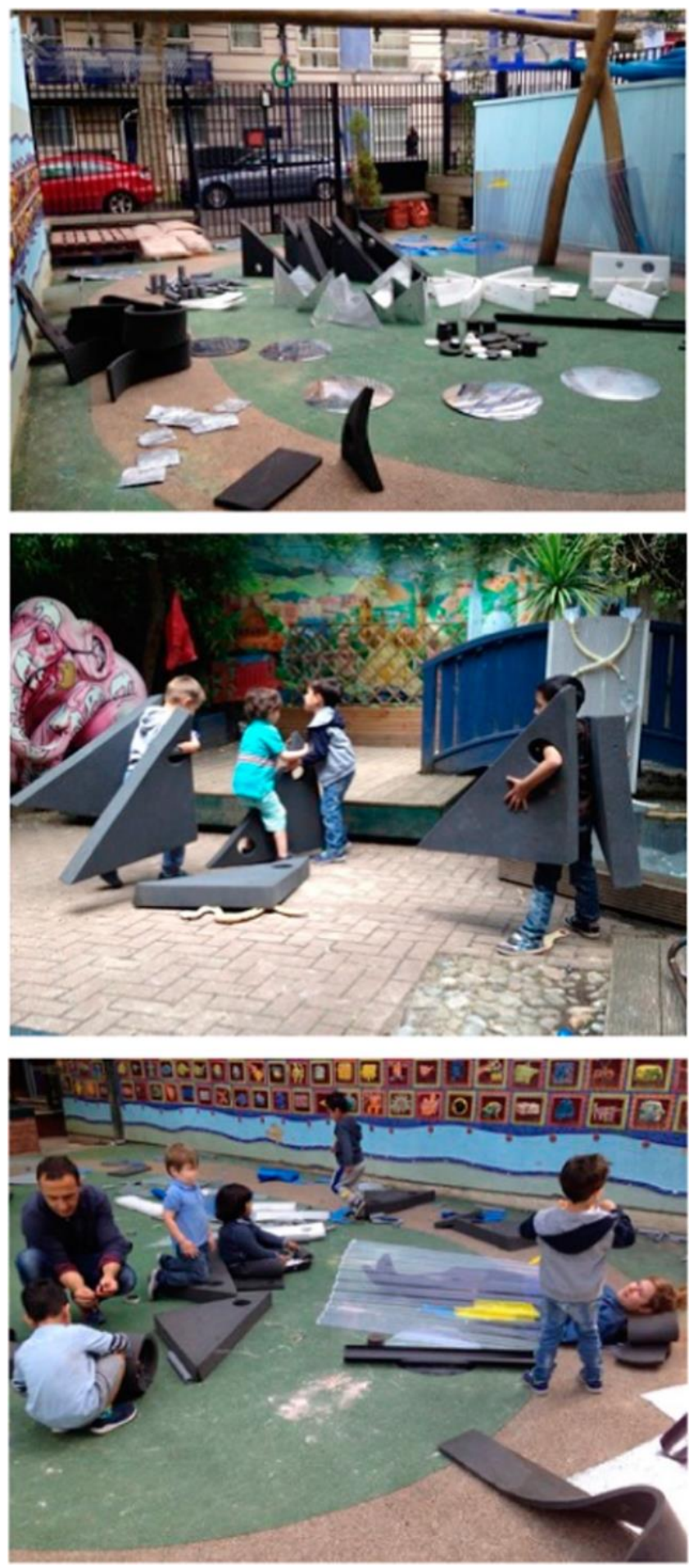

Figure 1. Visual text on the use of materials. 
For children, benefits of Changing Play included:

- Awareness and understanding of a range of materials and object and manipulative skills in handling large and small materials and objects and ability to conceptualise them in form and use

- Imaginative development in the interaction with materials, objects and other children, allowing experimentation in applying and combining of materials

- Linguistic development in the use of words, utterances and in the construction of narratives accompanying play and reflecting on it afterwards is essential in early conceptual development (Vygotsky 1978; Piaget 1928)

- The richness of children's narratives incorporated their understanding of social relations and responses to immediate and mediated culture - many instances of children making references to familiar media characters (notably Power Rangers) and to their experience of social and cultural life (home life, rockets, putting people in prison) (Marsh 2000)

- The ability to 'read' materials and objects, to adapt them to their imaginative purposes, to name things in their play-world and to construct complex narratives are all powerful precursors aiding the development of literacy in its many aspects

- Looking at the images the artist had taken of the children in play and then reflecting on them later, interpreting them and making narratives helped in the development of memory

- Particularly apparent was children's increasing sense of autonomy in the playworlds they created affording them a clearer sense of their own developing character and personhood, particularly in relation to others. Children were able to lead adults into and through their imaginative worlds, involving them in their play.

Figure 2. Writing in report mode

While we are able to provide detailed notes and images that confirm these statements, we are also aware that the participatory action research process of documentation under- taken throughout Changing Play was in part the forum through which these views were developed. Interviews with artists, learning curators and centre staff were not isolated from such discussions and often reaffirmed the kinds of formal and informal conversations that had been part of the iterative planning. We have of course had the benefit of being able to revisit notes and also to bring more formal pedagogical thinking to the writing. However, there is very little that is surprising to anyone involved in Changing Play about our reporting of results.

We are uneasy about our lack of 'new things to say' - perhaps we harbour a lingering desire to say something unexpected and insightful at the end of the project which might show that our involvement as external evaluators was indeed 'value for money'. Or perhaps it is simply that we find that the distanced evaluator position so at odds with the ongoing conversation that was the dominant mode of our other preferred positionings as collaborating action researchers, appreciative scholarly narrators and critical friends. We suspect that it is these montage texts (Thomson, McKelvie, and Turvey forthcoming 2019) which may contain material that is 'new' to our commissioners and co-researchers at the Serpentine.

We can say with some confidence, however, that the various texts that we have produced are certainly testament to the messiness of this project and the mobility of our ethnographic selves. We are relatively confident that we are not the only educational ethnographers to find ourselves attempting to put together the loose parts of our own positioning, and to produce texts that mirror this slipperiness. We would certainly like to read more discussions of the various ambivalences and balances that occur in these kinds of projects, and to see more textual experimentation that seeks to bring form and content closer together.

\section{References}

Ball, Stephen J. 2003. "The Teacher's Soul and the Terrors of Performativity." Journal of Education Policy 18 (2): 215-228. doi: 10.1080/0268093022000043065.

Barnett, Ron. 2010. Being a University. London: Routledge.

Barone, Tom. 2000. Aesthetics, Politics, and Educational Inquiry. Essays and Examples. New York: Peter Lang.

Bauman, Zygmunt. 2000. Liquid Modernity. Cambridge: Polity Press.

Becker, Howard. 1984. Art Worlds. Berkeley, CA: University of California Press. 
Benjamin, Walter. 2002. The Arcades Project. Translated by Kevin Eiland and Kevin McLaughlin. Boston, MA: Belknap/Harvard University Press.

Berger, Arthur Asa. 1997. Narratives in Popular Culture, Media and Everyday Life. London: Sage.

Bishop, Claire. 201 2. Artificial Hells. Participatory art and the Politics of Spectatorship. London: Verso.

Clark, Alison, and Peter Moss. 2001. Listening to Young Children. The Mosaic Approach. London: National Children's Bureau.

Coles, Rebecca, and Pat Thomson. 2016. "Beyond Records and Representations: Inbetween Writing in Educational Ethnography." Ethnography and Education 11 (3): 253-66. doi:10.1080/ 17457823.2015 .1085324$.

Conquergood, Dwight. 2013. Cultural Struggles. Performance, Ethnography, Praxis. Ann Arbor, Ml: University of Michigan Press.

Criado, Tomas Sanches, and Adolfo Estalella. 2018. "Introduction." In Experimental collaborations. Ethnography through fieldwork devices, edited by Adolfo Estalella and Tomas Sanchez Criado. New York: Berghann.

Dahlberg, Gunilla, and Peter Moss. 2004. Ethics and Politics in Early Childhood Education. London: Routledge.

de Certeau, Michel. 1988. The Practice of Everyday Life. Translated by S Randall. Los Angeles: University of California Press.

Denzin, Norman K. 2003. Performance Ethnography: Critical Pedagogy and the Politics of Culture. Thousand Oaks: Sage.

Derrida, Jacques. 1978. Writing and Differance. Translated by Alan Bass. 1995 ed. London: Routledge.

Elsaesser, Thomas, and Malte Hagener. 2016. Film Theory. Second ed. London: Routledge.

Elwick, Alex, Jayne Osgood, Leena Robertson, Mona Sakr, and Dilys Wilson. 2018. "In Pursuit of Quality: Early Childhood Qualifications and Training Policy." Journal of Education Policy 33 (3): 510-25.

Fisher, Elizabeth, and Rebecca Fortnum. 2014. On not Knowing. How Artists Think. London: Black Dog Publishing.

Gandini, Lella, Lynn Hill, Louise Cadwell, and Charles Schwall. 2005. In the Spirit of the Studio. Learning from the Atelier of Reggio Emilia. New York: Teachers College Press.

Geertz, Clifford. 1973. The Interpretation of Cultures. New York: Basic Books.

Gether, C., S. Høholt, D. Juul Rugaard, and C. Jalving. 2015. Palle Nielsen: The Model. Ishøi: ARKEN Museum of Modern Art.

Goetschius, George, and Joan Tash. 1967. Working with Unattached Youth. Problem, Approach, Method. London: Routledge \& Kegan Paul.

Haraway, Donna. 1990. "A Manifesto for Cyborgs: Science, Technology, and Socialist Feminism in the 1980s." In Feminism/Postmodernism, edited by L Nicholson, 190-233. London: Routledge.

Holmwood, John. 2011 . A Manifesto for the Public University. London: Bloomsbury Academic.

Ingold, Tim. 2011 . Being Alive. Essays on Movement, Knowledge and Description. London: Routledge.

Jones, Kip. 2006. "A Biographic Researcher in Pursuit of an Aesthetic: The Use of Arts-Based (re)Presentations in "Performative" Dissemination of Life Stories." Qualitative Sociology Review 2 (1): 66-85.

Kester, Grant. 2011 . The One and the Many. Contemporary Collaborative art and the Many. Durham, NC: Duke University Press.

Kress, G. R., and T. van Leeuwen. 2001. Multimodal Discourse: the Modes and Media of Contemporary Communication. London: Arnold.

Law, John. 2004. After Method: Mess in Social Science Research. London: Routledge.

Leavy, Patricia. 2009. Method Meets Art: Arts-Based Research Practice. New York: The Guildford Press.

Lewis, Zoe. 2018. "Policy and the Image of the Child: a Critical Analysis of Drivers and Levers in English Early Years Curriculum." Early Years: An International Research Journal. doi: 10.1080/09575146.2018.1501552.

Maclure, Maggie. 2010. "The Bone in the Throat: Some Uncertain Thoughts about Baroque Method." International Journal of Qualitative Studies in Education 19 (6): 729-745.

MacLure, Maggie, Rachel Holmes, Christina Macrae, and Liz Jones. 2010. "Animating Classroom Ethnography: Overcoming Video-Fear." International Journal of Qualitative Studies in Education 23 (5): 543-556.

Marsh, J. 2000. "Teletubby tales: popular culture in the early years language and literacy curriculum." Contemporary Issues in Early Childhood 1 (2): 1 19-33.

Mitchell, W. J. T. 2005. What do Pictures Want? The Lives and Loves of Images. Chicago: University of Chicago Press.

Nespor, Jan. 2000. "Anonymity and Place in Qualitative Inquiry." Qualitative Inquiry 6 (4): $546-569$.

Nicholson, Simon. 1971. "How not to Cheat Children: Theory of Loose Parts." Landscape Architecture 62: 30-34. Nicholson, Simon. 1972. "The Theory of Loose Parts." Studies in Design Education Craft \& Technology 4 (5-14).

Pandian, Anand, and Stuart McLean. 2017. Crumpled Paper Boat: Experiments in Ethnographic Writing. Durham: Duke University Press.

Paneth, Marie. 1944. Branch Street: A Sociological Study. London: George Allen and Unwin.

Piaget, Jean. 1928. The child's conception of the world. London: Routledge \& Kegan Paul.

Pink, Sarah. 2006. The Future of Visual Anthropology. Engaging the Senses. London: Routledge.

Pink, Sarah. 2009. Doing Sensory Ethnography. Thousand Oaks: Sage.

Pritchard, Steven. 2017. "Art Washing: Social Capital \& Anti-Gentrification Activism." In Colouring-in Culture. Accessed 18 June 2017. http://colouringinculture.org/blog/artwashingsocialcapitalantigentrification. 
Rabinow, Paul. 2007. Making Time: On the Anthropology of the Contemporary. Princeton, NJ: Princeton University Press.

Rabinow, Paul, George Marcus, James D Faubion, and Tobias Rees. 2008. Designs for an Anthropology of the Contemporary. Durham: Duke University Press.

Rancière, Jacques. 2009. The Emancipated Spectator. Translated by Gregory Elliott. London: Verso.

Riddle, Stewart, David Bright, and Eileen Honan. 2018. Writing with Deleuze in the Academy. Creating Monsters. Dordrecht: Springer.

Rinaldi, Carla. 2005. In Dialogue with Reggio Emilia. Listening, Researching and Learning. London: Routledge.

Schneider, Arndt, and Christopher Wright. 2010. Between art and Ethnography. Contemporary Ethnographic Practice. London: Bloomsbury.

Schneider, Arndt, and Christopher Wright. 2013. "Ways of Working." In Anthropology and Art Practice, edited by Arndt Schneider and Christopher Wright, 1-24. London: Bloomsbury

Stanislavsky, K. S. 1967. An Actor Prepares. Middx: Penguin Books.

Swales, John. 1990. Genre Analysis: English in Academic and Research Settings. Cambridge: Cambridge University Press.

Taussig, Michael. 1992. The Nervous System. New York: Routledge.

Taussig, Michael. 1997. The Magic of the State. New York: Routledge.

Taussig, Michael. 2006. Walter Benjamin's Grave. Chicago: University of Chicago Press.

Taussig, Michael. 2012. "I'm so Angry I Made a Sign." Critical Inquiry 39 (1):56-88.

Taussig, Michael. 2018. Palma Africana. Chicago: University of Chicago Press.

Thomson, Pat. 2018. "Troubling Writing as 'Representation'." In Ethnographic Writing, edited by B. Jeffrey and L. Russell. London: Tufnell Press. http://www.ethnographyandeducation.org/?page_id = 466: Ethnography and Education.

Thomson, Pat, and Helen Gunter. 2011 . "Inside, Outside, Upside Down: the Fluidity of Academic Researcher 'Identity' in Working with/in School." International Journal of Research \& Method in Education 34 (1): 17-30. doi: $10.1080 / 1743727 X .2011 .552309$.

Thomson, Pat, Amy McKelvie, and Leanne Turvey. Forthcoming. "Learning the art Museum: Experiments in Talking/Writing Ethnography." In Learning, Arts and Ethnography in a Contemporary World, edited by Lígia Ferro and David Poveda. London: Tufnell Press.

Tuck, Eve, and K. Wayne Yang. 2014. "Introduction." In Youth Resistance Research and Theories of Change, edited by Eve Tuck and K. Wayne Yang. New York: Routledge.

VanSlyke-Briggs, Kjersti. 2009. "Consider Ethno-Fiction." Ethnography and Education 4 (3): 335-345

Vecchi, Vea. 2010. Art and Creativity in Reggio Emilia. New York: Routledge.

Vygotsky, Lev. 1978. Mind in society: The development of higher psychological processes. Cambridge, MA: Harvard University Press. 